\title{
Journal of Multilingual Education Research
}

\section{Liberating Instruction: A Critical Bilingual Literacy Approach for Latinx Students}

Anel V. Suriel

Rutgers Graduate School of Education, anel.suriel@gse.rutgers.edu

Follow this and additional works at: https://research.library.fordham.edu/jmer

Part of the Bilingual, Multilingual, and Multicultural Education Commons

\section{Recommended Citation}

Suriel, Anel V. (2020) "Liberating Instruction: A Critical Bilingual Literacy Approach for Latinx Students," Journal of Multilingual Education Research: Vol. 10 , Article 7.

DOI: https://doi.org/10.5422/jmer.2020.v10.106-110

Available at: https://research.library.fordham.edu/jmer/vol10/iss1/7

This Book/Multimedia Review is brought to you for free and open access by Fordham Research Commons. It has been accepted for inclusion in Journal of Multilingual Education Research by an authorized editor of Fordham Research Commons. For more information, please contact considine@fordham.edu,bkilee@fordham.edu. 


\section{Liberating Instruction: A Critical Bilingual Literacy Approach for Latinx Students}

\section{Cover Page Footnote}

About the Author:

Anel V. Suriel is a doctoral student at the Rutgers Graduate School of Education. Her research interests broadly include language education policy practices, language teacher education, and the identity formation of multilingual students in American classrooms. She was a Bilingual Literacy Instructor for grades 3-8 in New York City and in New Jersey for thirteen years, and she currently serves as the Graduates Student Representative for NJTESOL/NJBE.

Acknowledgment: Cover graphic from En Comunidad by Carla España and Luz Yadira Herrera. Copyright (C) 2020 by Carla España and Luz Yadira Herrera. Published by Heinemann, Portsmouth, NH. Reprinted by permission of the publisher. All rights reserved. 


\section{Book Review}

\section{Liberating Instruction: A Critical Bilingual Literacy Approach for Latinx Students}

Anel V. Suriel

Rutgers Graduate School of Education

\section{Book Reviewed:}

España, C., \& Herrera, L. Y. (2020). En Comunidad: Lessons for Centering the Voices and Experiences of Bilingual Latinx Students. Heinemann. ISBN 978-0-325-112480 / 0-325-11248-7. 208 pages/Paperback \$30.63; ebook ${ }^{\mathrm{i}}$

In En Comunidad: Lessons for Centering the Voices of Experiences of Bilingual Latinx Students Dr. Carla España and Dr. Luz Yadira Herrera create the one-stop instructional text teachers need to honor and build from the experiences of bilingual Latinx students. Via a critical and culturally sustaining approach to language and literacy instruction, the book guides educators in creating units of study that center and leverage the experiences of Latinx students for learning.

En Comunidad begins with a foreword by Ofelia García who highlights the authors' stance on literacy education: a critical bilingual literacies approach. This

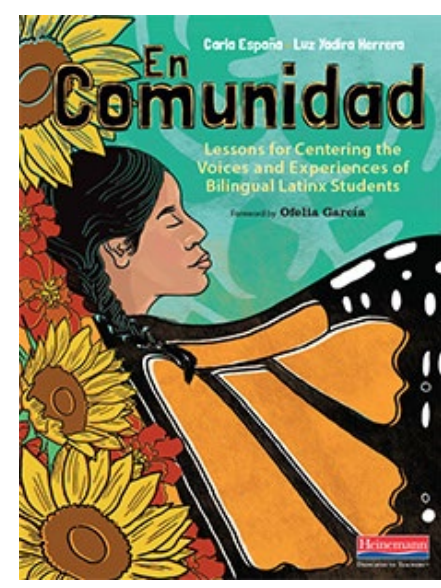
approach sees students' bilingual language practices as a strength and recognizes the diversity of bilingual Latinx literacy practices. By centering these practices in and for classroom learning, students are liberated from hierarchical, language power constructs that emphasize the superiority of English. They are free to engage their cultural, linguistic, and literacy practices for learning. In this way, the authors' critical bilingual literacies approach is restorative as students learn to identify, reject, and undo the normed practices that marginalize them and their communities. For these reasons, En Comunidad provides educational practitioners with a literacy approach that draws directly from students' and communities' funds of cultural and linguistic knowledge (Moll et al., 1992) and enacts culturally and linguistically sustaining pedagogies (Paris \& Alim, 2017). 
The book is easy to read without being time consuming, and its organization is practical and accessible. Each chapter is structured to help educational practitioners create reading and writing units surrounding a theme relevant to the experiences of bilingual Latinx learners. Colors differentiate between unit components to facilitate reference. A white background surrounds the introduction to each unit and a sequence of lessons. Supports for translanguaging practices (García et al., 2017) follow in yellow boxes. Step-by-step, principled guidance for creating thematic lessons follow immediately after in purple.

Within the units, the authors provide extensive thematic, grade-specific lists of culturally relevant texts in green. All texts employ authentic bilingual language practices and are thematically aligned to the unit goals. This makes finding texts, guiding questions, model charts, and lesson activities easy. There is room for flexibility in execution across any language setting in grades three through eight. All lessons and units can be easily aligned to grade level learning standards, and the translanguaging recommendations ensure the meaningful participation of emerging bilinguals. En Comunidad includes translanguaging practices within the text itself. As such, the authors allow the educator-reader to experience translanguaging (García et al., 2017; Vogel \& García, 2017) first-hand. This helps familiarize educators with translanguaging as a linguistic practice (Vogel \& García, 2017) while also revealing the power of the instructional methodology. All chapters conclude with suggestions for sharing learning outcomes with real audiences, and the authors are careful to give due attention to issues of students' personal safety in sharing their experience with classmates and in community contexts.

Chapter one begins with a short but powerful critical vignette. All chapters of En Comunidad begin with similar moments from either Dr. España's or Dr. Herrera's personal teaching experiences and are followed by a theoretical discussion around the goals of the unit. These exemplify and facilitate personal reflection on educational and language stances (García et al., 2017). Creating and enacting critically sustaining language and literacy pedagogies requires continuous self-examination. These stances on language and literacy are essential to liberating instruction from the traditions that have historically delegitimized Latinx students. This work begins with six principles for understanding of bilingual Latinx experiences and language practices. These principles are paired with questions for personal reflection. The six principles ask educators to reflect on language ideologies, enact a pedagogy that focuses on unlearning and undoing the effects of internalized dominant English hierarchies, engage in the analysis of language and power, and celebrate the bilingual practices of Latinx students from their perspectives. These principles are essential to leveraging bilingual Latinx students' language practices and experiences for learning while liberating students from normed deficit perspectives in literacy instruction.

Chapter two supports the creation of a language stance through the careful examination of language ideologies and practices. This enables instructors to recognize and understand how personal stances are influenced by language, power, and culture dynamics in school-based policies and practices. España and Herrera recommend that educators undertake this work first with colleagues as they may be unconsciously influenced by the same language ideologies that the units of the book aim to undo and 
critique. As such, En Comunidad encourages educators to work toward and enact a transformative stance that creates space for authentic language use in the classroom. The chapter includes charts and guiding questions to support this work and action recommendations for further learning both from and with students. By creating and enacting an equitable, justice-minded stance on language and literacy practices, España and Herrera enable teachers to create a safe space for dynamic learning through meaningful and authentic interactions around language and literacy.

Chapter three supports the work of story writing through immersion in texts that reflect students' authentic bilingual language uses. Students learn to tell their stories using their entire linguistic repertoire (Vogel \& García, 2017). They begin by reading and learning from texts that potentially employ the same language practices as the students themselves. This is essential to the success of emergent bilingual students (García, et al., 2017) as it validates their increasing complex and dynamic use of language. The authors include a wide variety of accessible classroom texts available in Spanish, English and bilingually. From there, students write their stories in their own voice. The chapter concludes with suggestions for sharing their stories in authentic contexts within the school or with community members.

Chapter four empowers students to resist and challenge master narratives by producing counter narratives that honor their personal histories and community experiences. The unit begins with the careful reflection of moments in which the authors and Latinx students first encounter their personal histories and experiences in texts and classroom learning. For many, this takes place in university-based ethnic studies classes. The authors undo this practice by allowing students to see themselves honorably and accurately represented in texts as young learners. In this unit, students use mythology to explore ancient history, analyze naming practices, research social resistance movements, and identify and create counter-narratives. The chapter engages students in conversation surrounding race and history, and the authors provide samples of charts, guiding questions, and suggestions for navigating emotionally charged moments. It includes a variety of diverse texts and formats to support student exploration. Students conclude this unit by sharing what they have learned through narratives that honor their communities and reveal the restorative power of resistance and hope. España and Herrera remind teachers that this work must also be undertaken by teachers and instructors. This is to ensure that instructional practices accurately reflect and build toward an educational stance that truly values and builds from students' cultural experiences. Because teachers may be unfamiliar with the Latinx histories and social movements presented in the texts of these chapters, it is important to research and learn about these experiences in order to center them in the inquiry of the unit. This includes teachers and larger school audiences bearing witness to students' stories. Just as bilingual Latinx students are overlooked in historical and literacy curricula, their peers are also deprived of hearing and learning from these stories and histories. Student produced counter-narratives thus serve the larger purpose of undoing marginalizing practices in school curricula and policies.

In chapter five, students engage in social justice by researching and acting against contemporary narratives that dehumanize them within the school, community, or beyond. While the authors use the topic of immigration for this series of lessons, they 
provide a list of high-interest contemporary topics that may be also used for this work. Here, España and Herrera advise educators to learn as much as they can about students' backgrounds and experiences. This will help educators understand how students have been and continue to be impacted by dehumanizing master narratives surrounding race and immigration. The authors again provide supports to facilitate difficult conversations as students work to identify and undo internalized narratives of linguistic and cultural inferiority. This is essential to the safety of individual students and the classroom environment as students question and understand the master narratives within primary and secondary resources surrounding immigration. Suggestions for student-led action on the school level and beyond are included at the end of the chapter. This social justice based action reinforces resistance skills that reject oppression and inferiority while directly countering narratives that dehumanize students, their communities, and their language practices.

Chapter six focuses on poetry and the power of the genre to explore and teach others about students' language practice and experiences. The unit engages students in readings of poetry that connect to students' bilingual experiences through authentic language practices and exploration. Students are encouraged to develop and perform their own poetry that incorporates the same. Guiding questions for discussion and translanguaging analysis are also included. This chapter speaks directly to the healing potential of the genre for students' identity formation. As students teach others about their own experience and language uses, they both resist deficit ideologies related to their language and cultural practices while sustaining their communities. This chapter is dedicated to empowering student voices and identities through literacy.

The final chapter of the book implores teachers to act as advocates, edu-activists, for bilingual Latinx students. Educators must consistently learn and reflect on their educational and language stances and encourage the same in others. This work begins at the school level, but it extends beyond the classroom as developed in chapters one through six. Edu-activists may begin by creating a plan of action for centering students and their experiences in the school curriculum through advocacy efforts. They must also create alliances with like-minded faculty that teach from social justice and culturally sustaining standpoints. These can be expanded outside of the school as well. This is a process that requires constant reflection and analysis. The chapter concludes with a call to expand this work into other aspects of teaching and learning and continuous research and exploration. As the authors point out, this chapter, and this text, are the starting point to an equitable, actionable, critical pedagogy.

This final call to action gives attention to the need to work with and research into the language and historical lived experiences of marginalized students and racial ethnic groups in order to equally center them in curricular and instructional practice. Because this text addresses the Latinx experience exclusively, educators must be careful to remember their students from other backgrounds. The recommended steps in the final chapter can help teachers and curriculum writers find and incorporate equally rich and respectful texts, topics, and experiences of other marginalized groups. En Comunidad leaves an open call for similar instructional support texts that address the practices and experiences of other language communities. 
The authors also claim this work is limited to practice and texts appropriate to grades 3-8. However, the concepts and practices described in the book can extend to high school with immense benefits to students' developing academic, cultural, and linguistic identities - especially in its call to social justice. Attention to this grade level group can be a beneficial additional chapter or appendix to subsequent editions of the book. Across all grade levels, the lessons and suggested texts easily align to grade level standards and can engage students in authentic, critical learning through elementary, middle, and high school.

It is clear that Dr. España and Dr. Herrera kept in mind the day-to-day experience of language classroom instruction when writing En Comunidad. It is accessible, easy to read and digest, and its principles are easy to employ. It is this ease of use-alongside the restorative power of its practice-that makes this volume an essential and must-have text for educators working directly with Latinx students and language teacher candidates in higher education.

\section{References}

García, O., Johnson, S.I., Seltzer, K. (2017). The translanguaging classroom: Leveraging student bilingualism for learning. Caslon.

Moll, L., Amanti, C., Neff, D., \& González, N. (1992). Funds of knowledge for teaching: Using a qualitative approach to connect homes and classrooms. Theory into Practice, 31(2),132-141. http://search.proquest.com/docview/62848283/

Paris, D., \& Alim, H. S. (2017). Culturally sustaining pedagogies: Teaching and learning for justice in a changing world. Teachers College Press.

Vogel, S., \& García, O. (2017, December). Translanguaging. In G. Noblit \& L. Moll (Eds.), Oxford research encyclopedia of education. Oxford University Press.

\section{End Note}

' Cover graphic: From En Comunidad by Carla España and Luz Yadira Herrera. Copyright (C) 2020 by Carla España and Luz Yadira Herrera. Published by Heinemann, Portsmouth, $\mathrm{NH}$. Reprinted by permission of the publisher. All rights reserved. 